\title{
Lethal congenital contracture syndrome: further delineation and genetic aspects
}

\author{
Katri Vuopala, Riitta Herva
}

\begin{abstract}
In a national morphology based study of lethal arthrogryposis between 1979 and 1992, 40 fetuses and infants with lethal congenital contracture syndrome (LCCS, McKusick 253310) were found in Finland. The incidence of LCCS in Finland was 1:19000 births. There were 20 affected males and 20 affected females in 26 families. In 16 cases the pregnancy was terminated after the prenatal diagnosis of total akinesia and fetal hydrops on ultrasound. There were 19 stillborn infants and five were born showing signs of life, but died within one hour. The segregation analyses yielded 0.45 affected by the "singles" method and 0.34 by the "sib" method. The birthplaces of the grandparents were located in the sparsely populated north east of Finland. This finding supports the existence of an autosomal recessive LCCS gene in Finland, particularly in the north eastern part.
\end{abstract}

(f Med Genet 1994;31:521-527)

The lethal congenital contracture syndrome (LCCS) is an autosomal recessive syndrome (McKusick 253310) leading to perinatal death. Affected fetuses present a typical phenotype with hypoplastic jaw, low set ears, hypoplastic lungs, and contractures of the extremities, with overextended knees. Similar features always occur when a fetus does not move and the phenotype is called the fetal akinesia deformation sequence. ${ }^{1}$ In LCCS the abnormalities are very severe and typically there is also fetal hydrops which can be detected by ultrasound from the 14th gestational week. ${ }^{2}$ The fetal akinesia in LCCS is caused by the degeneration of descending tracts and anterior horn motor neurones of the spinal cord. ${ }^{3}$

LCCS was originally described in 10 families no familial cases have been reported elsewhere. However, a few sporadic cases similar to LCCS have been published. ${ }^{56}$ As part of the classification of lethal arthrogryposis, an epidemiological and genealogical study on LCCS was carried out in Finland.

Department of Pathology, University of Oulu, Kajaanintie 52D, FIN-90220 Oulu, Finland

K Vuopala

R Herva

Correspondence to Dr Vuopala.

Received 29 September 1993 publication 13 January 1994

\section{Materials and methods}

Cases of lethal arthrogryposis in Finland have been collected since 1979 . A prospective study was begun in 1988 with a request for information about cases with lethal arthrogryposis and instructions for necropsy in the fournal of the Finnish Medical Association in 1988. A personal from north eastern Finland. ${ }^{4}$ As far as we know,

visit was made to the five university hospitals (Helsinki, Kuopio, Oulu, Tampere, and Turku) in Finland, in which complicated deliveries are treated and genetic counselling and paediatric pathology are performed. The material comprised 91 cases of which 40 met the diagnostic criteria of LCCS: early hydrops and fetal akinesia, lethality, the Pena-Shokeir phenotype, and specific neuropathology with the degeneration of anterior horn of the spinal cord and an extreme skeletal muscular atrophy. ${ }^{3}$

Necropsies were performed in the local central hospitals. In prospective cases the brain and spinal cord were fixed in entirety and skeletal muscle samples were frozen. The fixed CNS and frozen muscle samples were sent to the Department of Pathology of the Oulu University Hospital with photographs, $x$ rays, necropsy records, family data, and clinical history.

Postmortem study consisted of routine necropsy and neuropathological investigation. The specimens were fixed in phostate buffered $10 \%$ formalin. After washing, dehydration, and embedding in paraffin, serial $6 \mu \mathrm{m}$ sections were cut and stained with eosin and haematoxylin. Skeletal muscle samples were frozen in isopentane, cooled with liquid nitrogen, and stored at $-70^{\circ} \mathrm{C}$. Serial frozen sections were routinely processed. $^{7}$

To determine pulmonary hypoplasia, lung weight ${ }^{8}$ or radial alveolar count were used as the criteria for diagnosis. ${ }^{9}$ Intrauterine growth was compared to the latest Finnish standards ${ }^{10}$ in cases older than 24 gestational weeks and to international standards in the rest of the cases. ${ }^{11}$ Clinical data were collected from hospital records. The abortion frequency was compared with that in the normal population. ${ }^{12}$

Differences in regional gene frequencies were assessed by the grandparents' birthplaces. The birthplaces were confirmed from the population register. For the incidence calculation the number of annual births until 1990 was obtained from the Statistical Yearbook of Finland, and those during 1991 and 1992 by personal communication from Statistics Finland. Segregation analysis was performed with the singles methods ${ }^{13}$ and the a priori method, ${ }^{14}$ which both assume truncate complete ascertainment, and with the sib method, ${ }^{15}$ which assumes single incomplete ascertainment.

\section{Results}

Clinical details are summarised in table 1 . The material included a total of 40 LCCS cases, 20 males and 20 females in 26 families (fig 1). The studied (1979-1992) was 1:19000 births. This means five new cases in Finland yearly. incidence of LCCS calculated for the period 
Table 1 Summary of the clinical features and necropsy findings

\begin{tabular}{|c|c|c|c|c|c|c|c|c|c|c|c|c|c|c|c|c|c|}
\hline Case & $1 a$ & $1 b$ & $1 c$ & $1 d$ & $2 a$ & $2 b$ & $2 c$ & 3 & $4 a$ & $4 b$ & $5 a$ & $5 b$ & 6 & 7 & 8 & 9 & $10 a$ \\
\hline Sex & $\mathrm{F}$ & $\mathbf{F}$ & $\mathbf{M}$ & $\mathbf{M}$ & $\mathbf{F}$ & $\mathbf{M}$ & $\mathbf{F}$ & $\mathbf{F}$ & $\mathbf{M}$ & $\mathbf{F}$ & $\mathbf{M}$ & $\mathbf{M}$ & $\mathbf{F}$ & $M$ & $\mathbf{F}$ & $\mathbf{M}$ & $\mathbf{F}$ \\
\hline Age of the mother $(y)$ & 34 & 35 & 37 & 39 & 24 & 26 & 27 & 25 & 32 & 33 & 21 & 22 & 32 & 20 & 32 & 24 & 23 \\
\hline Gestational age (w) & 28 & 30 & 18 & 17 & 21 & 20 & 19 & 26 & 28 & 17 & 35 & 32 & 31 & 34 & 33 & 27 & 26 \\
\hline Survival (minutes, hours, days) & 0 & 0 & ia & ia & 0 & ia & ia & 0 & 0 & ia & $\min$ & 0 & 0 & 0 & 0 & 0 & 0 \\
\hline Apgar score (at $1 / 5 / 10$ minutes) & 0 & 0 & & & 0 & & & & 0 & & 1 & 0 & 0 & 0 & 0 & 0 & 0 \\
\hline Diminished fetal movements & & & & & & & & & & + & & + & + & + & & + & \\
\hline Prenatal diagnosis & - & + & + & + & - & + & + & & - & + & & & & + & & & \\
\hline Hydrops & - & + & + & + & + & + & + & - & - & + & + & + & + & + & + & + & + \\
\hline Polyhydramnios & + & - & - & & - & & & & & - & & & & + & + & & - \\
\hline IUGR & + & + & + & + & - & - & - & + & + & - & + & + & + & + & + & - & + \\
\hline Birth weight (g) & 820 & 1140 & 90 & & 3900 & 440 & 310 & & 910 & & 1740 & 430 & 880 & 1200 & 1335 & 690 & 550 \\
\hline $\begin{array}{l}\text { Birth CH length }(\mathrm{cm}) \\
\text { Birth CR length }(\mathrm{cm})\end{array}$ & 36 & 36 & 18 & 16 & $\begin{array}{l}24 \\
18\end{array}$ & 24 & 22 & 24 & & & 35 & 31 & 34 & 40 & 39 & 22 & \\
\hline $\begin{array}{l}\text { Birth CR length (cm) } \\
\text { Pterygia }\end{array}$ & $\mathrm{n}$ & $\mathrm{n}, \mathrm{e}$ & $e^{13}$ & 11,5 & $e^{18}$ & $e^{19}$ & 16 & $e^{16}$ & & 13 & & & & & & e & e \\
\hline Lung hypoplasia & + & + & + & + & & & + & & & & + & + & + & + & + & + & + \\
\hline Fractures of long bones & $\mathrm{H}, \mathrm{F}$ & $\mathbf{F}$ & & $\mathbf{F}$ & & & & & & $\mathbf{F}$ & $\mathbf{F}$ & & $\mathrm{F}$ & & & & \\
\hline Spinal cord pathology & & + & & & + & + & + & & & + & & & & & & & \\
\hline Muscle pathology & + & & & + & & & & & & & & & & & & & \\
\hline
\end{tabular}

ia $=$ induced abortion, $\mathrm{n}=$ neck, $\mathrm{e}=$ elbow, $\mathrm{H}=$ humerus, $\mathrm{F}=$ femur. Families $1-6$ have been reported previously. ${ }^{4}$



Figure 1 In 26 families there were 20 affected males, 20 affected females, 11 spontaneous abortions, and five stillborn fetuses.

PREGNANCY AND DELIVERY

The mother reported diminished fetal movements in 13 cases. Prenatal diagnosis was done on the basis of total fetal akinesia and hydrops on ultrasound in 24 cases. In 16 of these, the family chose termination of pregnancy, and in the rest of the cases the pregnancy continued.
Of these eight pregnancies seven ended before term with abortion or stillbirth, and one with the birth of a male infant in the 33rd gestational week. He died at the age of one minute. In the rest of the 16 pregnancies without prenatal diagnosis, there were 12 stillborn and four infants showing signs of life at birth. The outcome of the infants was fatal in one hour. The mean gestational age was 27 weeks from the last menstrual period.

Besides the affected fetuses, there were 26 healthy sibs, seven spontaneous abortions, one extrauterine pregnancy, five stillborn fetuses, and four induced abortions, which were not studied and were excluded from the segregation analysis. The latter included one genetic termination (trisomy 21), and three terminations for social indications. The frequency of spontaneous abortion was $8.3 \%$, which is no higher than the abortion frequency in the normal population.

CLINICAL FINDINGS

Twenty fetuses were small (under 2 SD) for gestational age. Normal intrauterine growth was detected in all cases but one below 22 gestational weeks. Hydrops was verified in 37 fetuses, even in the severely autolysed. The face of all fetuses was peculiar with ocular hypertelorism, apparently low set and sometimes posteriorly angulated ears, and hypoplastic jaw. The limbs were of normal proportion, but looked stick-like because of the extreme muscle atrophy. Multiple joint contractures with a similar pattern was seen in all cases (fig 2). There were flexion contractures in the elbows, wrists, and hips. The knees were in marked hyperextension, the shoulders were adducted, and severe bilateral club foot was present. Pterygia were observed in 18 cases, most often in the elbows.

NECROPSY FINDINGS

Pulmonary hypoplasia was verified in 20 cases and muscle atrophy was macroscopically present in all cases and histologically verified in 19 cases. The spinal cord was available in 19 cases. It showed a marked reduction of the ventral part and a paucity of motor neurones (fig 3). Fractures of the long bones, most often the femur, were seen in six cases. 
Table 1 (cont)

\begin{tabular}{|c|c|c|c|c|c|c|c|c|c|c|c|c|c|c|c|c|c|c|c|c|c|c|}
\hline $10 b$ & $10 c$ & $10 d$ & $10 e$ & $11 a$ & $11 b$ & 12 & 13 & 14 & 15 & $16 a$ & $16 b$ & 17 & $18 a$ & $18 b$ & 19 & 20 & 21 & 22 & 23 & 24 & 25 & 26 \\
\hline $\begin{array}{r}M \\
24 \\
18 \\
0 \\
0\end{array}$ & $\begin{array}{l}\mathrm{F} \\
24 \\
15 \\
0 \\
0\end{array}$ & $\begin{array}{l}M \\
26 \\
16 \\
\text { ia }\end{array}$ & $\begin{array}{l}M \\
27 \\
20 \\
\text { ia } \\
+\end{array}$ & $\begin{array}{c}M \\
28 \\
29 \\
0 \\
0 \\
+\end{array}$ & $\begin{array}{c}M \\
30 \\
29 \\
0 \\
0 \\
+\end{array}$ & $\begin{array}{l}\mathrm{F} \\
23 \\
31 \\
0 \\
0\end{array}$ & $\begin{array}{l}\text { F } \\
36 \\
22 \\
\text { ia }\end{array}$ & $\begin{array}{r}M \\
28 \\
20 \\
0 \\
0 \\
+\end{array}$ & $\begin{array}{l}M \\
17 \\
22 \\
\text { ia }\end{array}$ & $\begin{array}{l}\mathrm{F} \\
23 \\
37 \\
1 \mathrm{~d} \\
1 / 3 / 4\end{array}$ & $\begin{array}{l}\text { F } \\
28 \\
19 \\
\text { ia }\end{array}$ & $\begin{array}{l}\mathrm{F} \\
35 \\
28 \\
0 \\
0\end{array}$ & $\begin{array}{l}\mathrm{F} \\
21 \\
36 \\
50 \mathrm{~min} \\
1 / 0 / 1 \\
+\end{array}$ & $\begin{array}{l}M \\
22 \\
17 \\
\text { ia }\end{array}$ & $\begin{array}{l}\text { F } \\
17 \\
24 \\
\text { ia } \\
+\end{array}$ & $\begin{array}{l}M \\
28 \\
27 \\
\text { ia } \\
+\end{array}$ & $\begin{array}{l}M \\
27 \\
24 \\
\text { ia }\end{array}$ & $\begin{array}{l}\text { M } \\
39 \\
19 \\
\text { ia } \\
+\end{array}$ & $\begin{array}{l}\mathrm{F} \\
23 \\
32 \\
10 \mathrm{~min} \\
1 / 1\end{array}$ & $\begin{array}{l}M \\
22 \\
33 \\
1 \mathrm{~min} \\
1\end{array}$ & $\begin{array}{l}M \\
22 \\
20 \\
\text { ia }\end{array}$ & $\begin{array}{l}\mathbf{F} \\
32 \\
24 \\
0 \\
+\end{array}$ \\
\hline+ & + & + & + & - & + & & + & + & + & & + & - & & + & + & + & + & & + & + & + & \\
\hline+ & + & + & + & + & + & + & + & $\stackrel{+}{-}$ & + & $\stackrel{+}{+}$ & + & + & $\begin{array}{l}+ \\
+\end{array}$ & + & + & + & + & & + & + & + & + \\
\hline $\begin{array}{l}- \\
135 \\
18 \\
14\end{array}$ & $\begin{array}{l}- \\
46 \\
13 \\
10\end{array}$ & $\begin{array}{l}- \\
60 \\
14 \\
11\end{array}$ & $\begin{array}{l}- \\
230 \\
20 \\
15\end{array}$ & $\stackrel{+}{660}$ & $\begin{array}{l}- \\
1250 \\
40\end{array}$ & $\begin{array}{l}+ \\
771 \\
34\end{array}$ & $\overline{670}$ & $\begin{array}{l}- \\
320 \\
22 \\
17\end{array}$ & $\begin{array}{l}- \\
440 \\
21\end{array}$ & $\begin{array}{l}+ \\
2240 \\
35\end{array}$ & $\begin{array}{l}- \\
170 \\
23\end{array}$ & $\begin{array}{l}+ \\
610 \\
31 \\
22\end{array}$ & $\begin{array}{l}+ \\
1539 \\
38\end{array}$ & $\begin{array}{l}- \\
112 \\
29 \\
12\end{array}$ & $\begin{array}{l}+ \\
365 \\
32 \\
16\end{array}$ & $\begin{array}{l}+ \\
730 \\
22\end{array}$ & $\begin{array}{l}+ \\
490 \\
20\end{array}$ & & $\begin{array}{l}- \\
1460 \\
14 \\
14\end{array}$ & $\begin{array}{l}+ \\
1210 \\
38 \\
26\end{array}$ & $\begin{array}{l}+ \\
172 \\
20 \\
20\end{array}$ & $\begin{array}{l}+ \\
336 \\
23 \\
23\end{array}$ \\
\hline $\begin{array}{l}\text { e } \\
+\end{array}$ & $\begin{array}{l}\text { n } \\
+ \\
+\end{array}$ & $\begin{array}{l}\text { e } \\
+ \\
+\end{array}$ & $\begin{array}{l}\text { e } \\
+ \\
+\end{array}$ & e & & & & $\begin{array}{l}\text { e.n. } \\
+ \\
+\end{array}$ & & + & + & $\begin{array}{l}\text { e } \\
+\end{array}$ & + & + & + & $\begin{array}{l}\text { e } \\
+\end{array}$ & + & & & & + & + \\
\hline $\begin{array}{l}+ \\
+\end{array}$ & + & + & + & & & & + & + & & + & + & + & + & + & + & + & + & & & + & + & + \\
\hline
\end{tabular}
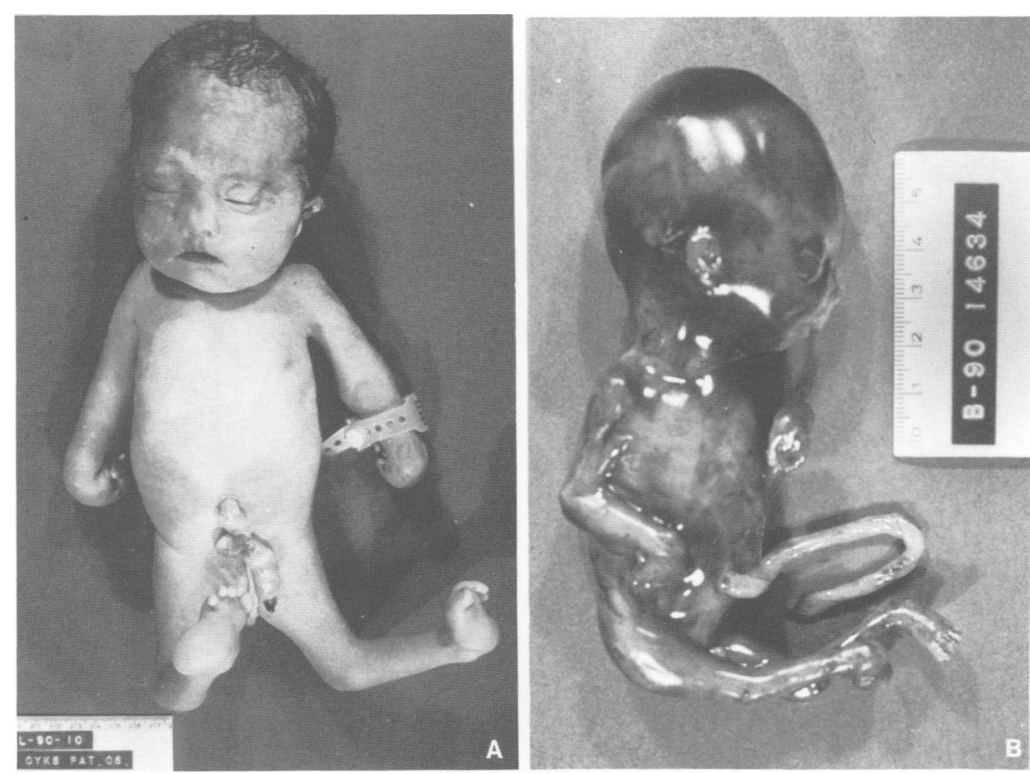

Figure 2 Typical cases of LCCS: (A) a 38 week old fetus and (B) a prenatally diagnosed 17 week old fetus from family 18.

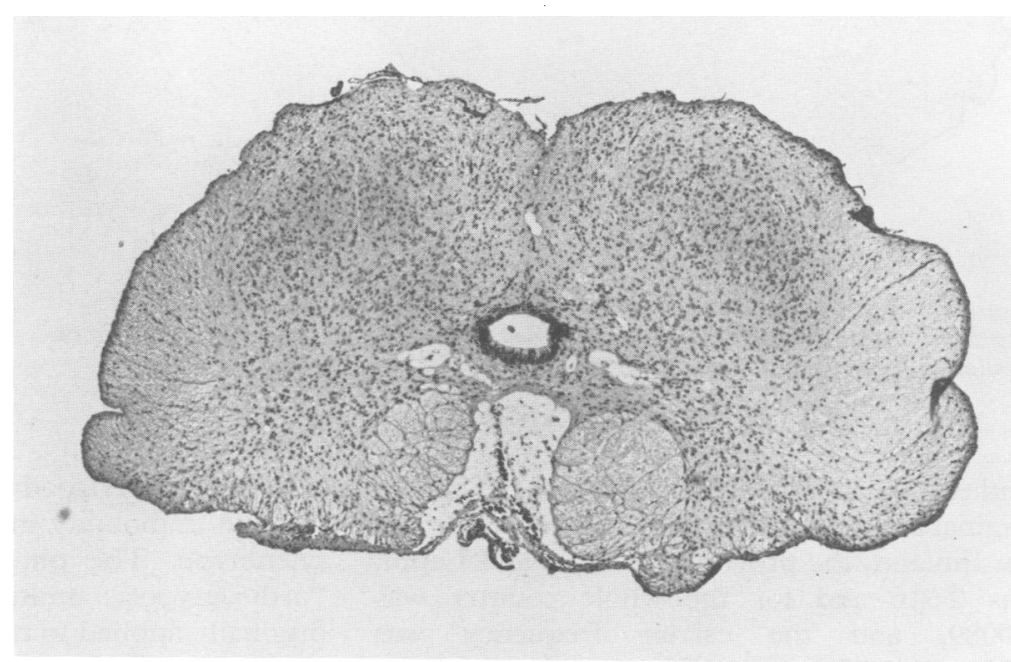

Figure 3 The spinal cord showed a marked reduction in the ventral part, a paucity of anterior motor neurones, and hydropic degeneration of descending tracks. ( $H$ and $E$ stain).

GENETIC ASPECTS

The segregation analysis of the pedigrees showed a ratio of affected sibs of 0.45 (SE 0.08) by the "singles method" and 0.34 (SE 0.07) by the "sib method". The observed number of patients (40) was higher than expected on the basis of recessive inheritance (32, SE 2.34) by the "a priori" method.

The birthplaces of the grandparents were used to illustrate the geographical distribution of LCCS in Finland. They were localised in the sparsely populated north eastern area of Fin- 


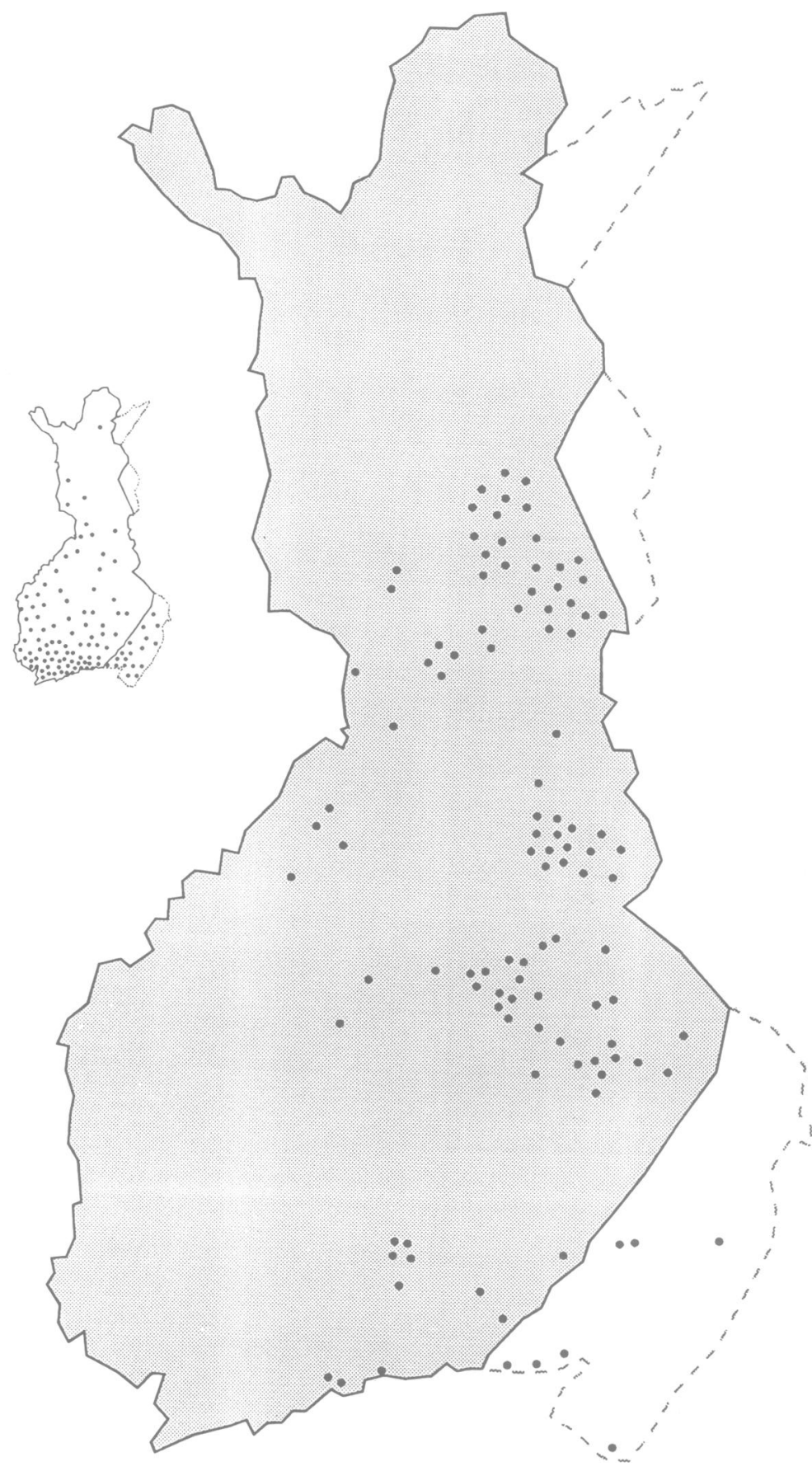

Figure 4 The birthplaces of the grandparents were in north eastern Finland. The map shows the distribution of a respective number of marks arranged according to the population density of Finland.

land (fig 4), the same region as those of the 10 original families. The gene frequency for northern Finland, the provinces of Oulu and Lappi, was 0.016 and for the whole country was 0.0089 , and the carrier frequency was $1: 31$ and 1:57, respectively, calculated by the Hardy-Weinberg coefficient.

\section{Discussion}

Lethal congenital contracture syndrome (LCCS) is part of the fetal akinesia phenotype (FADS). The pathological mechanism of FADS was well documented by Moessinger. ${ }^{1}$ He curarised pregnant mice and the fetuses showed a classic picture of FADS with hypoplastic lungs and contractures of the extremi- ties. It is understood that any disorder which leads to immobility in utero causes the FADS phenotype. The phenotype has been called "arthrogryposis multiplex congenita", and it originally applied to multiple flexed joints present at birth. ${ }^{16}$ Nowadays, it is used in the more specific meaning of a phenotype in which there are joint contractures present in at least two areas of the body at birth with evidence of muscle wasting, but no evidence of progessive neurological disease. ${ }^{17}$ The overlapping term Pena-Shokeir syndrome, or more recent PenaShokeir I phenotype, was introduced after Pena and Shokeir ${ }^{18}$ reported two sisters who had severe camptodactyly, club feet, knee and hip ankylosis, facial anomalies, and pulmonary hypoplasia. Arthrogryposis multiplex congenita 
and Pena-Shokeir I phenotype are descriptive terms that cover several separate entities with fetal akinesia.

In the London Dysmorphology Database, LCCS is part of the Pena-Shokeir-multiple ankyloses-pulmonary hypoplasia syndrome. As stated in the abstract of the Database, PenaShokeir-multiple ankyloses-pulmonary hypoplasia covers a number of separate entities. We consider LCCS as a distinct entity within it. In LCCS there is a constant neuropathological finding with severe reduction of anterior horn of the spinal cord and total or nearly total absence of large motor neurones. Above the decussation of the pyramids, the CNS is normal. ${ }^{3}$ However, most reports of perinatally lethal cases referred to in the Database either present with abnormal brain development, such as immaturity, ${ }^{19}$ cortical ectopia, ${ }^{20}$ polymicrogyria or hypoplasia of the optic nerves and optic chiasma, ${ }^{21}$ multicystic encephalopathy, ${ }^{22}$ hemiatrophy of the temporal lobe,,$^{23}$ hydrencephaly, ${ }^{24}$ or present with brain damage, ${ }^{25}$ or with a well preserved spinal cord, ${ }^{232527-29}$ or lack complete neuropathological study. ${ }^{18-202729-33}$ LCCS also has a unique, severe clinical picture. It is always fatal during the fetal period, and it presents with hydrops, severe intrauterine growth retardation, and extreme hypoplasia of skeletal muscle. ${ }^{34}$ The prenatal diagnosis can be achieved as early as the 13th gestational week..$^{35}$ In families with recurrent cases, the affected fetuses have been detected by sonography without exception before the 20th week of gestation. The fetuses have shown joint contractures, hydrops, and no movement. As discussed later, LCCS is an autosomal recessive syndrome with a recurrence risk of $25 \%$, which is higher than the 10 to $15 \%$ risk in the Pena-Shokeir syndrome, as stated in the London Dysmorphology Database.

There are only a few studies on the incidence of arthrogryposis. In a Finnish study of 36711 live born infants, it was found to be $1: 3000 .^{36}$ The material included four perinatally lethal cases in one family. The same incidence of arthrogryposis was found in a Canadian series of 350 affected newborns, of which $29(8 \%)$ died in the first year of life. ${ }^{37}$ According to these two studies, lethal arthrogryposis is estimated to occur once in every 37500 births, which is about half the incidence calculated for LCCS in the present study. The increased occurrence can be explained by the recognition of the FADS phenotype and growing interest in perinatally lethal cases. Complicated pregnancies are treated nowadays in university hospitals, in which paediatric pathology services and more exact diagnosis are available.

The present study confirms the original clinical findings of LCCS. Both male and female fetuses were equally affected. Prenatal diagnosis could be made by ultrasound even in the 14th week of gestation when hydrops appeared and fetal movements diminished. In the present cases prenatal diagnosis was achieved in $60 \%$ of cases, whereas in the original study the frequency was $25 \%$. Prenatal diagnosis is also reliable in sporadic cases. Polyhydramnios was usually found in the third trimester of pregnancy, whereas the fetal hydrops appeared ear- lier and was detected even in severely macerated cases. The mean gestational age in the present cases was a little less than in the original study. A few pregnancies continued, instead of the earlier 33 weeks, until the 36th week from the last menstrual period. The outcome was still very poor and all pregnancies ended fatally before term. The longest survival was 50 minutes. Intrauterine growth retardation of the fetuses was not seen in cases terminated before the 23 rd gestational week, but appeared in most older cases.

The original study of 10 families suggested autosomal recessive inheritance of LCCS, but the number of affected fetuses was too high. In the sibships there were 16 affected fetuses, eight unaffected children, six spontaneous abortions of unknown type, and five stillborn fetuses, which were not studied. In the present study the number of affected fetuses was again high in comparison to that expected for autosomal recessive inheritance. This can be explained by the small size of sibships and the youth of the mothers, who had not yet passed their fertile age. The family planning possibilities might also have affected the results of segregation analysis. Three of the families had chosen sterilisation and one couple was divorced after having an affected fetus. It is possible that a few sporadic cases in families with healthy sibs could have gone undiagnosed or misdiagnosed.

The gene and carrier frequencies of LCCS in Finland and especially in northern Finland are high. This is in line with the specific pattern of hereditary diseases in Finland, overrepresentation of some, mostly autosomal recessive disorders, and lack of diseases which are common in other countries. This specific pattern of hereditary diseases is the result of the national and regional isolation of the small population which is especially pronounced in sparsely populated north eastern Finland. ${ }^{38}$ Most of the ancestors of the LCCS families originated from this area.

The modern methods of molecular genetics can provide further understanding of LCCS. The second generation linkage mapping using polymorphic loci containing short tracks of $(\mathrm{C}-\mathrm{A})_{\mathrm{n}}$ repeats has made gene mapping of rare genetic diseases more effective. ${ }^{39}$ As the pathogenesis of LCCS is interpreted to be the degeneration of anterior horn motor neurones and the autosomal recessive form of childhood onset SMA has been mapped to chromosome $5 q 12.2-13,4041$ the $5 q$ region is the first object of the study. The locus has been refined to the interval between D5S435 and MAP1B, ${ }^{42}$ and recently 5cen-D5S76-D5S6-D5S125-SMA(5'MAP-1B-3' MAP-1B)/D5S112-JK53CA1/ 2-(D5S39-D5S127)-5qter. ${ }^{43}$ However, the diagnostic criteria for spinal muscular atrophy ${ }^{44}$ proposed by the International SMA Consortium include arthrogryposis as an exclusion criterion. Linkage studies on lethal SMA cases with arthrogryposis have so far shown no confirmation of the $5 q$ location. ${ }^{45}$ The second locus which needs to be excluded is $21 \mathrm{q} 21.1-22.1$, the locus for familial amyotrophic lateral sclerosis, ${ }^{46}$ in which anterior horn cells in the spinal cord are also affected.

The exaggeration of naturally occurring 
Table 2 Neurotrophin mapped in human genome

\begin{tabular}{llll}
\hline Neurotrophin & $\begin{array}{l}\text { Human } \\
\text { chromosome }\end{array}$ & Locus & Reference \\
\hline NGF & 17 & $17 \mathrm{q} 12-22$ & 53 \\
$\beta$-subunits & 1 & $1 \mathrm{p} 22$ & 54 \\
NGF receptor & 17 & $1 \mathrm{p} 13$ & 55 \\
NT-3 & 12 & $17 \mathrm{q} 21-\mathrm{qter}$ & 56 \\
& & $17 \mathrm{q} 12-17 \mathrm{q} 22$ & 57 \\
NT-4 & 19 & $12 \mathrm{p} 13$ & 58 \\
NT-5 & 19 & $19 \mathrm{q} 13.3$ & 59 \\
CNTF & 11 & $11 \mathrm{q} 12$ & 61 \\
BDNF & 11 & $11 \mathrm{p} 13-\mathrm{p} 14$ & 62 \\
& & $11 \mathrm{p} 15.5-\mathrm{p} 11.2$ & 58 \\
& & $11 \mathrm{p} 13$ & 59 \\
\hline
\end{tabular}

motor neurone death was proposed to be a part of the anterior horn damage in SMA. ${ }^{47}$ In LCCS this mechanism could play an important role, because the degeneration of anterior horn motor neurones in LCCS overlaps the time of naturally occurring death of the motor neurones during fetal development. ${ }^{48}$ Recently, motor neurone survival has been showed to be promoted by neurotrophins. ${ }^{49-52}$ Thus, this family of growth factors, their receptors, or mediators may be involved with the pathogenesis of LCCS. The neurotrophins have been mapped in the human genome as shown in table 2 , giving hints for linkage analysis. On a purely speculative basis the candidate genes could be located in chromosomes $1 \mathrm{p}, 5 \mathrm{q}, 9 \mathrm{q}, 11 \mathrm{p}, 17 \mathrm{q}$, and 21q. A linkage study on the present cases is in progress.

The authors wish to thank the clinical geneticists and pathologists for contributing cases for the study, especially Drs Pekka Laurila, Leo Paliärvi, and Riitta Salonen, and the Emil Aaltonen Foundation for financial support.

1 Moessinger AC. Fetal akinesia deformation sequence: an animal model. Pediatrics 1983;72:857-63.

2 Kirkinen P, Herva R, Leisti J. Early prenatal diagnosis of a lethal syndrome of multiple congenital contractures. Prenat Diagn 1987;7:189-96.

3 Herva R, Conradi NG, Kalimo H, Leisti J, Sourander P. A syndrome of multiple congenital contractures: neuropathological analysis on five cases. Am f Med Genet 1988;29:6776.

4 Herva R, Leisti J, Kirkinen P, Seppänen U. A lethal autosomal recessive syndrome of multiple congenital contractures. Am $\Im$ Med Genet 1985;20:431-9.

5 Imamura M, Yamanaka N, Nakamura $F$, Oyanagi $K$. Arthrogryposis multiplex congenita: an autopsy case of a fatal form Hum Pathol 1981;12:699-703.

6 Moerman P, Fryns JP, Goddeeris P, Lauweryns JM. Multiple ankyloses, facial anomalies, and pulmonary hypoplasia associated with severe antenatal spinal muscular atrophy. $f$ Pediatr 1983:103.238-41.

7 Brooke MH, Kaiser KK. Three 'myosin adenosine triphosphatase' systems: the nature of their $\mathrm{pH}$ lability and sulfhydryl dependence. $\mathcal{f}$ Histochem Cytochem 1970 18:670-2.

8 Potter EL, Craig JM, eds. Pathology of the fetus and infant. Chicago: Year Book Medical Publishers, 1975:21.

9 Askenazi SS, Perlman M. Pulmonary hypoplasia: lung weight and radial alveolar count as criteria of diagnosis. Arch Dis Child 1979;54:614-18.

10 Pihkala J, Hakala T, Voutilainen P, Raivio K. Uudet suomalaiset sikiön kasvukäyrät (in Finnish). Duodecim 1989;105:1540-6.

11 Streeter GL. Weight, sitting height, head size, foot length and menstrual age of human embryo. Contrib Embryol 1920;11:143.

12 Hemminki K, Mutanen P, Saloniemi I, Niemi NL, Vainio H. Spontaneous abortions in hospital staff engaged in
sterilizing instruments with chemical agents. $B M \mathcal{F}$ 1982;285:1461-3.

$13 \mathrm{Li} \mathrm{CC}$, Mantel N. A simple method of estimating the segregation ratio under complete ascertainment. $A m \mathcal{J}$ Hum Genet 1968;20:61-8.

14 Hogben L. The genetic analysis of familial traits. Single gene substitutions. $f$ Genet 1931;25:97-112.

15 Fisher RA. The effects of methods of ascertainment upon the estimation of frequencies. Ann Eugen 1934;6:13-25.

16 Stern WG. Arthrogryposis multiplex congenita. $\mathfrak{f} A M A$ 1923;81:1507-10.
17 Fisher RL, Johnston WT, Fisher WH Jr, Goldkamp OG. Arthrogryposis multiplex congenita: a clinical investigation. F Pediatr 1970;76:255-61.

18 Pena SDJ, Shokeir MHK. Syndrome of camptodactyly, multiple ankylosis, facial anomalies and pulmonary hypoplasia: a lethal condition. $\mathcal{f}$ Pediatr 1974;85:373-7.

19 Besceglia N, Zelante L, Bosman C, Cera R, Dallapiccola B. Pathological features in two siblings with the Pena-Shokeir I syndrome. Eur $¥$ Pediatr 1987;146:283-7.

20 Chen H, Blumberg L, Immken L, et al. The Pena-Shokeir syndrome: report of five cases and further delineation of the syndrome. Am $\mathcal{F}$ Med Genet 1983;16:213-24.

21 Lazjuk GI, Cherstvoy IW, Luries MK, Nedzved MK. Pulmonary hypoplasia, multiple ankyloses, and camptodactyly: one syndrome or some related forms? Helv Paedactyly: one syndrome or

22 Choi BH, Ruess WR, Kim RC. Disturbances of neuronal migration and laminar cortical organization associated with multicystic encephalopathy in the Pena-Shokeir syndrome. Acta Neuropathol 1986;69:213-24.

23 Itoh K, Yokoyama N, Ishihara A, et al. Two cases of fetal akinesia/hypokinesia sequence. Pediatr Pathol 1991; 11:467-77.

24 Hageman G, Willemse J, Van Ketel BA, Verdonck AFMM. The pathogenesis of fetal hypokinesia: a neurological study of 75 cases of congenital contractures with emphasis on cerebral lesions. Neuropediatrics 1987;18:22-33.

25 Dimmink JE, Berry K, MacLeod PM, Hardwick DF. Syndrome of ankyloses, facial anomalies, and pulmonary hypoplasia: a pathologic analysis of one infant. Birth Defects 1977;8:133-7.

26 Lavi E, Montone KT, Rorke LB, Kliman HJ. Fetal akinesia deformation sequence (Pena-Shokeir phenotype) associated with acquired intrauterine brain damage. Neurology 1991;41:1467-8.

27 Shenker DM, Reed K, Anderson C, Hauck L, Spark R. Syndrome of camptodactyly, ankyloses, facial anomalies, and pulmonary hypoplasia (Pena-Shokeir syndrome): obstetric and ultrasound aspects. Am $\mathcal{f}$ Obstet Gynecol 1985;152:303-7.

28 Toriello HV, Bauserman SC, Higgins JV. Sibs with fetal kinesia sequence, fetal edema, and malformations: a new syndrome? Am $¥$ Med Genet 1985;

29 Williams RS, Holmes LB. The syndrome of multiple ankyoses and facial anomalies. Acta Neuropathol 1980;50: 75-9.

30 Gyr T, Katz M, Altermatt HJ, et al. Lethal Pena-Shokeir 1 syndrome in three male siblings. Arch Gynecol Obstet 992;251:149-54.

31 Mailhanes JB, Lancaster K, Bourgeois MJ, Sanusi ID. 'Pena-Shokeir syndrome" in a newborn male infant. $A m \dot{\jmath}$ Dis Child 1977;131:1419-20.

32 Mease AD, Yeatman GW, Pettett G, Merenstein GB. A syndrome of ankylosis, facial anomalies and pulmonary hypoplasia secondary to fetal neuromuscular dysfunction. Birth Defects 1976;12:193-200.

33 Punnett HH, Kistenmacher ML, Valdes-Dapena M, Ellison RT. Syndrome of ankylosis, facial anomalies and pulmonary hypoplasia. $\mathcal{F}$ Pediatr $1974 ; 85: 375-7$.

34 Verloes A, Dodinval P, Retz MC, Schaaps JP, Koulischer L. A hydropic fetus with translucent ribs, arthrogryposis multiplex congenita and congenital myopathy: etiological heterogeneity of AMC, Toriello-Bauserman type? Genet Counsel 1991;2:63-5.

35 Kirkinen P, Herva R, Leisti J. Early prenatal diagnosis of a lethal syndrome of multiple congenital contractures. Prenat Diagn 1987;7:189-96.

36 Laitinen O, Hirvensalo M. Arthrogryposis multiplex congenita. Ann Paediatr Fenn 1966;12:133-8.

37 Hall JG. Genetic aspect of arthrogryposis. Clin Orthop 1984;194:44-53.

38 Norio R. Diseases of Finland and Scandinavia. In: Rothschild $\mathrm{H}$, ed. Biocultural aspects of disease. New York: Academic Press, 1981:359-415.

39 Weissenbach J, Gyapay G, Dib C, et al. A second-generation linkage map of the human genome. Nature 1992;359:794-

40 Brzustowicz LM, Lehner T, Castilla LH, et al. Genetic mapping of chronic childhood-onset spinal muscular atrophy to chromosome 5q11.2-13.3. Nature 1990;344: 540-1.

41 Melki J, Abdelhak S, Sheth P, et al. Gene for chronic proximal muscular atrophies maps to chromosome 5q. Nature 1990;344:767-8.

42 Soares VM, Brzustowicz LM, Kleyn PW, et al. Refinement of the spinal muscular atrophy locus to the interval between D5S435 and MAP1B. Genomics 1993;15:365-71.

43 Wirth B, Voosen B, Rohrig D, et al. Fine mapping and narrowing of the genetic interval of the spinal muscular trophy region by linkage studies. Genomics 1993;15:113-8.

44 Munsat TL. Workshop report. International SMA collaboration. Neuromusc Disord 1991;1:81.

45 Lunt PW, Mathew C, Clark S, et al. Can prenatal diagnosis be offered in neonatal lethal spinal muscular atrophy (SMA) with arthrogryposis and fractures? $f$ Med Genet 1992;29:272-85.

46 Eubanks JH, Puranam RS, Kleckner NW, Bettler B, Heinemann SF, McNamara JO. The gene encoding the glutamate receptor subunit GluR5 is located on human chromosome 21q21.1-22.1 in the vicinity of the gene for familial amyotrophic lateral sclerosis. Proc Natl Acad Sci USA 1993;90:178-82.

47 Hausmanowa-Petrusewicz I, Fidzianska A, Niebroj-Dobosz I, Strugalska MH. Is Kugelberg-Welander spinal muscular atrophy a fetal defect? Muscle Nerve 1980; 3:389-402 
48 Forger NG, Breedlove SM. Motoneuronal death during human fetal development. $f$ Comp Neurol 1987;264:11822.

49 Yan Q, Elliott J, Snider WD. Brain-derived neurotrophic factor rescues spinal motor neurons from axotomy-induced cell death. Nature 1992;360:755-7.

50 Oppenheim RW, Qin-Wei Y, Prevette D, Yan Q. Brainderived neurotrophic factor rescues developing avian motoneurons from cell death. Nature 1992;360:757-9.

51 Sendtner M, Kreutzberg GW, Thoenen H. Ciliary neurotrophic factor prevents the degeneration of motor neurons phic factor prevents the degeneration
after axotomy. Nature 1990;345:440-1.

52 Hendersson CE, Camu W, Mettling C, et al. Neurotrophins promote motor neuron survival and are present in embryo-

53 Wright EC, Fain PR, Barker DF, Chao MV. A moderately frequent HindIII polymorphism at the human NGFR locus (17q12-17q22). Nucleic Acids Res 1989;17:825.

54 Dracopoli NC, Rose E, Whitfield GK, et al. Two thyroid hormone regulated genes, the beta-subunits of nerve growth factor (NGFB) and thyroid stimulating hormone (TSHB), are located less than $310 \mathrm{~kb}$ apart in both human and mouse genomes. Genomics 1988;3:161-7.

55 Garson JA, van den Berghe JA, Kemshead JT. Novel non isotopic in situ hybridization technique detects small $(1 \mathrm{~kb})$ unique sequences in routinely G-banded human chromosomes: fine mapping of N-myc and beta-NGF genes. Nucleic Acids Res 1987;15:4761-70.

56 Rettig WJ, Thomson TM, Spengler BA, Biedler JL, Old LJ.
Assignment of human nerve growth factor receptor gene to chromosome 17 and regulation of receptor expression in somatic cell hybrids. Somat Cell Mol Genet 1986;12:441-7.

57 Huebner $\mathrm{K}$, Isobe $\mathrm{M}$, Chao $\mathrm{M}$, et al. The nerve growth factor receptor gene is at human chromosome region 17q12-17q22, distal to the chromosome 17 breakpoint in acute leukemias. Proc Natl Acad Sci USA 1986;83:1403-7.

58 Ozcelik T, of brain-derived neurotrophic factor and neurotrophin-3 genes in man and mouse. Genomics 1991;10:569-75.

59 Maisonpierre PC, Le Beau MM, Espinosa R, et al. Human ansonpierre PC, Le Beau MM, Espinosa R, et al. Human and rat brain-derived neurotrophic factor and neurotrophin-3: gene structures, distributions,
localizations. Genomics 1991;10:558-68.

60 Ip NY, Ibanez CF, Nye SH, et al. Mammalian neurotrophin-4: structure, chromosomal localization, tissue distriphin-4: structure, chromosomal localization, tissue distri1992;98:3060-4.

61 Berkemeier LE, Ozcelik T, Francke U, Rosenthal A. Human chromosome 19 contains the neurotrophin-5 gene locus and three related genes that may encode novel acidic neurotrophins. Somat Cell Mol Genet 1992;18:233-45.

62 Giovannini M, Romo AJ, Evans GA. Chromosomal localization of the human ciliary neurotrophic factor gene (CNTF) to $11 \mathrm{q} 12$ by fluorescence in situ hybridization. Cytogenet Cell Genet 1993;63:62-3.

63 Hanson IM, Seawright A, van Heyningen V. The human BDNF gene maps between FSHB and HVBS1 at the boundary of 11p13-p14. Genomics 1992;13:1331-3. 